\title{
Regional disparity in summer monsoon precipitation in the Indian subcontinent during Northgrippian to Meghalayan transition
}

\author{
Som Dutt ${ }^{1}$ *, Anil K. Gupta ${ }^{2}$, Rahul Devrani ${ }^{1}$, Ram R. Yadav ${ }^{1}$ and Raj K. $\operatorname{Singh}^{3}$ \\ ${ }^{1}$ Wadia Institute of Himalayan Geology, 33, General Mahadeo Singh Road, Dehradun 248 001, India \\ ${ }^{2}$ Department of Geology and Geophysics, Indian Institute of Technology, Kharagpur 721 302, India \\ ${ }^{3}$ School of Earth, Ocean and Climate Sciences, Indian Institute of Technology Bhubaneswar, Argul 752 050, India
}

The present study reveals distinct spatial variability of summer monsoon precipitation in Indian subcontinent during Northgrippian to Meghalayan transition. Protracted dry phase lasting $\sim \mathbf{1 0 0 0}$ yrs was observed $\sim 4.2 \mathrm{ka} B P$ in southern and northwestern India whereas 200-300 yrs event occurred in northeastern parts. Strong El Niño conditions beginning $\sim 4.3$ kyr BP were associated with the millennial long dryness in western parts but its influence was limited in the eastern region. Cross-verified, high-resolution records from different geographic regions of India are still required to ascertain if regional differences occurred in span and magnitude during Northgrippian to Meghalayan transition.

Keywords: Indian summer monsoon, Indus civilization, Late Holocene, 4.2 ka event, Meghalayan age.

THE Holocene epoch has witnessed several episodes of warm and wet climate such as early Holocene warming, Roman Warm Period, Medieval climate anomaly interrupted by cold and dry events like $8.2 \mathrm{ka}$ event, $4.2 \mathrm{ka}$ event, Little Ice Age, etc. ${ }^{1-6}$. Amongst dry phases, the $4.2 \mathrm{ka}$ event was severe and widely studied because of its pronounced influence on ancient civilizations ${ }^{7-15}$. Pronounced aridity for $200-300$ yrs beginning at $\sim 4.2 \mathrm{kyr}$ BP is known to have caused population migration and the collapse of several ancient civilizations, e.g. Akkadian and Indus civilizations (IC) ${ }^{7,8,11,15}$. However, there are records which suggest protracted aridity between 4.4 and $1.9 \mathrm{kyr} \mathrm{BP}^{11,14,15}$.

Indian subcontinent suffered widespread aridity during the $4.2 \mathrm{ka}$ event due to weakened Indian Summer Monsoon $(\mathrm{ISM})^{8-10,11-15}$. Reduced precipitation led to water scarcity for agriculture and other needs of IC people and triggered population migration towards eastern and southern regions for better survival conditions $s^{8,11,14,15}$. Palaeoclimatic records display a diverse view of ISM precipitation in terms of gradual/abruptness and span, and its cultural influences in different regions of Indian mon-

*For correspondence. (e-mail: somdutt@wihg.res.in) soon domain ${ }^{1-6,8-15}$. Detailed reviews on ISM variability during Holocene are available ${ }^{1,2}$, but regional precipitation disparity in Indian subcontinent during the $4.2 \mathrm{ka}$ event is not much discussed. Here, we examined available marine and terrestrial proxy records of ISM variability from different regions in Indian subcontinent and northern Indian Ocean (IO) for better understandings of precipitation variability during Northgrippian to Meghalayan transition.

\section{Domain of ISM}

ISM precipitation is pivotal for socio-economic wellbeing of $1 / 3 \mathrm{rd}$ of human population living in Indian subcontinent. A moderate change in ISM intensity/amount or onset-retreat timings affects greatly the human lives, infrastructure, regional ecology and economy through disastrous floods and drought-induced famines. During boreal summers, the inter-tropical convergence zone (ITCZ) shifts northward and moisture-laden winds from IO enter into Indian subcontinent supplying $\sim 75 \%$ of annual precipitation between June and September ${ }^{16,17}$ (Supplementary Table 1). The Arabian Sea (AS) branch of the ISM strikes on west coast of India during the first week of June and then proceeds towards central and western India. The Bay of Bengal (BoB) branch first strikes in northeast India and then moves westwards along strike of the Himalaya.

\section{ISM proxy records}

A score of ISM proxy records from AS and BoB, and continental archives such as lakes, peats, speleothems, etc. from India are used in this review. Details of the records discussed in this study are given in Figure 1 and Supplementary Table 2. Based on meteorological data, India has been divided into five homogenous rainfall zones (excluding Himalayan region), i.e. peninsular India (PI), west-central India (WCI), northwest India (NWI), central northeast India (CNEI) and northeast India $(\mathrm{NEI})^{16}$. Proxy records are discussed accordingly. 


\section{REVIEW ARTICLES}

Himalayan records are divided into central and western Himalaya. Sites situated in NWI, CNEI and WCI exist in a typical ISM zone receiving $\sim 85 \%$ of precipitation between June and September, whereas central and western Himalaya also receive significant precipitation through mid-latitude westerlies during winters ${ }^{5,11,16,17}$ (Figure 1, Supplementary Table 1). Some parts of PI gets precipitation through NE monsoon during winters and NEI receives a significant rainfall during May and October.

\section{Discussion/analysis of regional monsoon records}

\section{Arabian Sea}

The $\delta^{18} \mathrm{O}$ ratios of planktic foraminifer Globigerinoides ruber from the Hole 63KA, northern AS show significant enrichment at $\sim 4.2 \mathrm{kyr}$ BP, suggesting a sudden salinity rise due to decline in Indus River discharge linked to reduced precipitation in western Himalaya through weakened ISM $^{13}$ (Figure $2 d$ ). The driest conditions occurred between 4.2 and $4.0 \mathrm{kyr}$ BP with weak ISM conditions lasting for $\sim 500 \mathrm{yrs}$ until $3.7 \mathrm{kyr}$ BP (Figure $2 d$ ). Recently, Giesche et al. ${ }^{9}$ suggest a weakening of the ISM $\sim 4.8 \mathrm{kyr}$ BP and the weakest phase occurred between 4.1 and 3.9 kyr BP. Reduced ISM winds intensity was observed over AS during that time ${ }^{3}$. Two episodes of decreased $\mathrm{Al}(\%)$ at site SK 148/55 were observed centred at 4.35 and $3.5 \mathrm{kyr} \mathrm{BP}$, suggesting less terrigenous input in AS with low ISM precipitation on land areas ${ }^{18}$ (Figure 2 c). During 4.2-1.5 kyr BP, AS oxygen minimum zone was intensified taking its present shape, marked by strong denitrification ${ }^{19,20}$. A decrease in benthic foraminifera species diversity, and Globigerina bulloides abundance, and increased dysoxic species at site $723 \mathrm{~A} \sim 4.2 \mathrm{kyr}$ BP that lasted till $1.5 \mathrm{kyr} \mathrm{BP}$, are attributed to weak ISM and

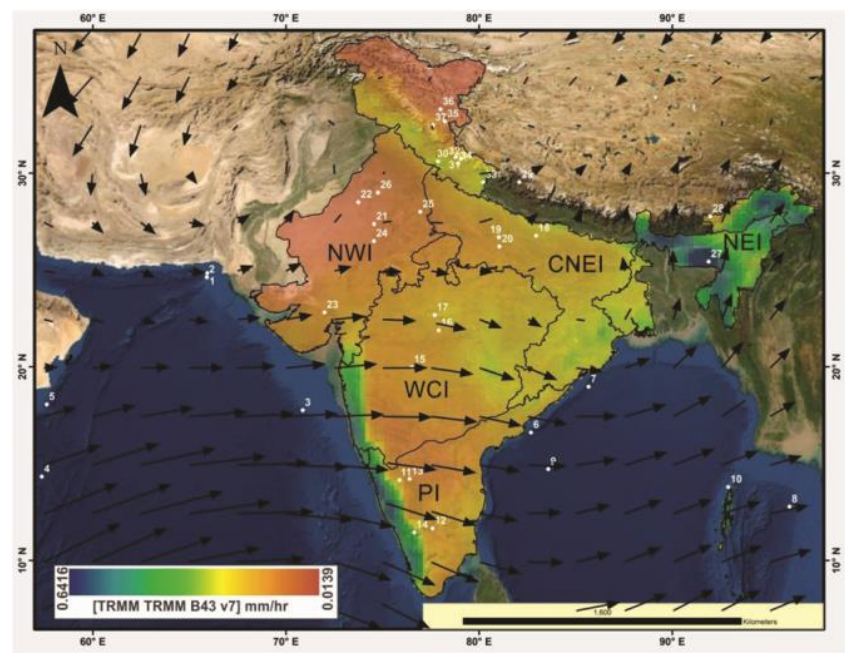

Figure 1. Map showing the location of sites whose data has been discussed in this study. Details are shown in Supplementary Table 2. enhanced flow of highly saline, oxygen-poor Red Sea water at intermediate depths of the AS, and reduced vertical mixing due to winter monsoon ${ }^{20}$ (Figure $2 a$ ). A 2-4 $\mathrm{m}$ of sea-level fall in AS was also suggested after middle Holocene ${ }^{21}$. The varve thickness near Karachi coast, Pakistan decreased between 3.8 and $3.6 \mathrm{kyr}$ BP linked to reduced Indus river discharge by less precipitation in the watershed upstream ${ }^{22}$ (Figure $2 e$ ). The Red Sea also witnessed a notable dry event at $\sim 4.2 \mathrm{kyr}$ BP as

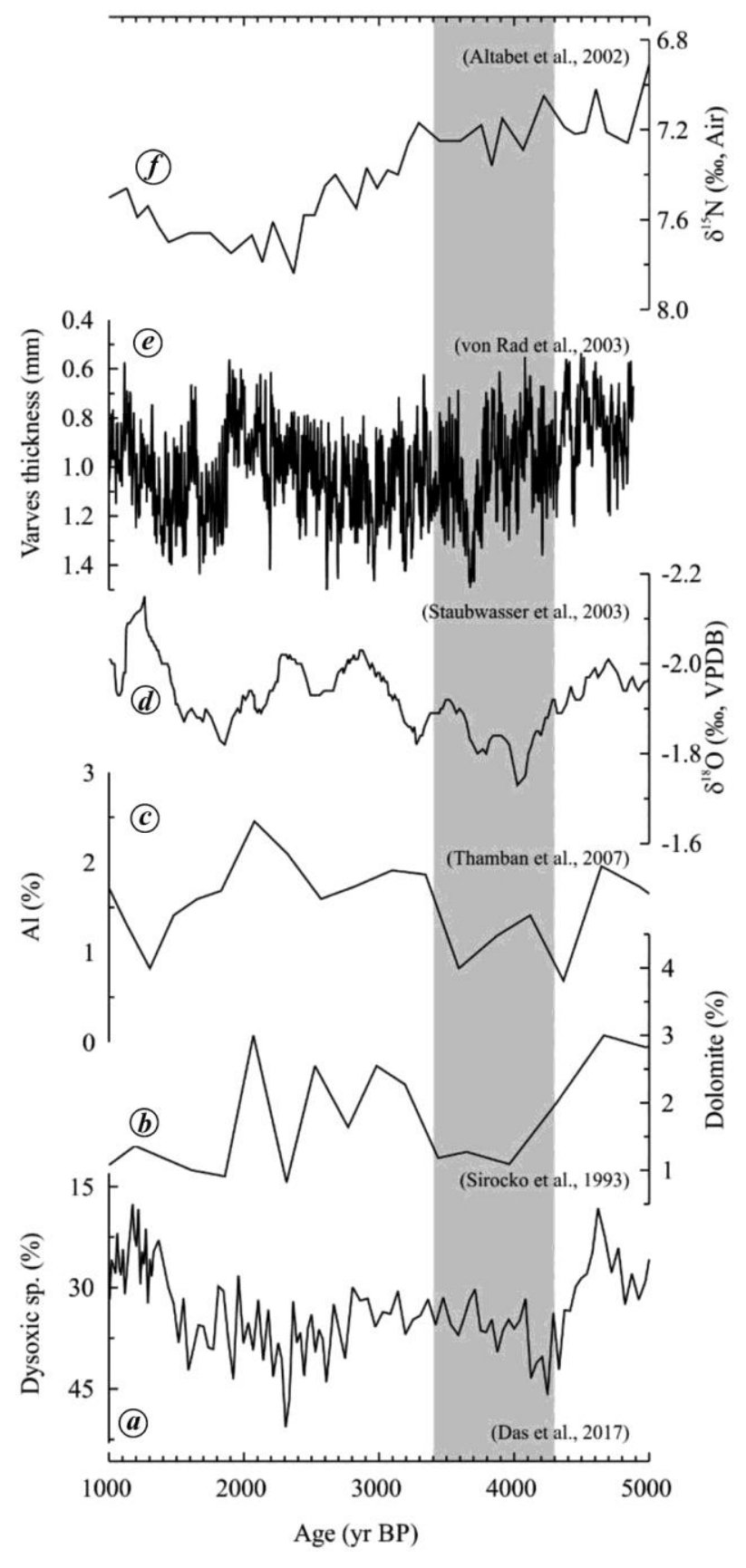

Figure 2. Indian summer monsoon variability proxy records from the Arabian Sea: $\boldsymbol{a}$, Hole 723A (ref. 20); $\boldsymbol{b}$, Site $74 \mathrm{KL}$ (ref. 25); $\boldsymbol{c}$, SK $148 / 55$ (ref. 18); $\boldsymbol{d}, 63 \mathrm{KA}$ (ref. 13); $\boldsymbol{e}$, SO $90-39$ (ref. 22); $\boldsymbol{f}, \delta^{15} \mathrm{~N}(\%$, air) from AS (ref. 19). 
evidenced by increased sea surface salinity lasting up to 4.0 kyr BP (ref. 23). A recent study from northeastern AS revealed arid events $\sim 4.2$ and $1.2-1 \mathrm{kyr}$ BP with ITCZ migration southwards that led increased westerlies influence on the sedimentation processes ${ }^{24}$. On the contrary, a decrease in the dolomite concentration in core $74 \mathrm{KL}$ between 4.6 and $3.4 \mathrm{kyr}$ BP has been ascribed to reduced dust concentration from the Arabian Peninsula due to wetter climate linked with strong ISM conditions ${ }^{25}$ (Figure $2 b$ ). However, the temporal resolution in this study is low.

\section{Bay of Bengal}

Enriched $\delta^{18} \mathrm{O}$ in $G$. ruber from cores RC12-344 and VM-29-19, BoB indicate lowered discharge from

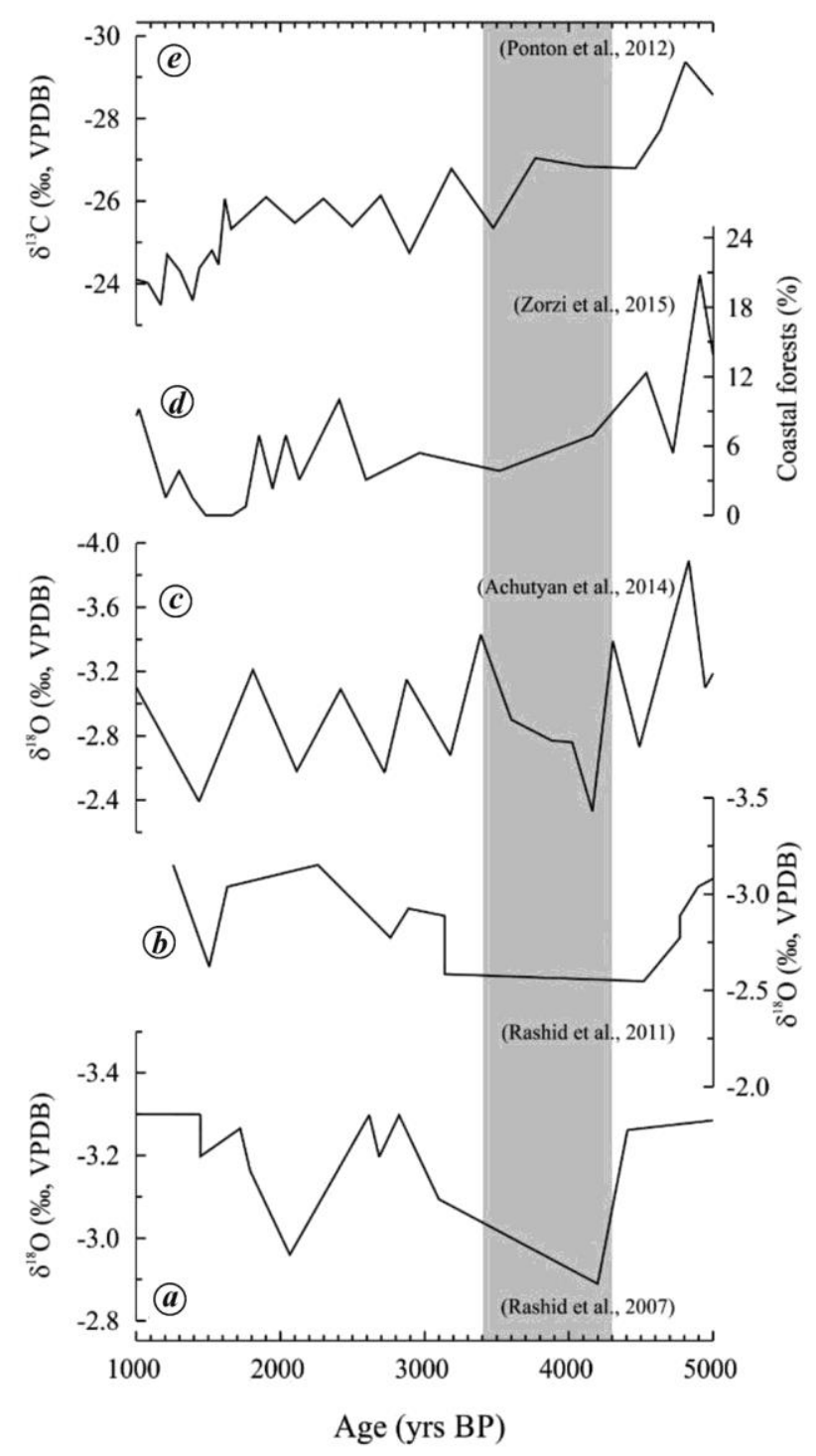

Figure 3. Indian summer monsoon variability proxy records from the Bay of Bengal: $\boldsymbol{a}, \mathrm{RC} 12-344$ (ref. 26); $\boldsymbol{b}$, VM-29-19 (ref. 27); $\boldsymbol{c}$, SNSC 03-2008 (refs 28, 29); $\boldsymbol{d}$, NGHP-01-16A (ref. 31); $\boldsymbol{e}$, NGHP-16A (ref. 32).
Ganga-Brahmaputra and Irrawaddy rivers linked to lowered ISM rainfall between 4.8 and 1.4 kyr BP (refs 26, 27) (Figure $3 a$ and $b$ ). Multi-proxy analyses of a gravity core SNSC 03-2008 from Landfall Island region, north Andaman indicate higher smectite, lowered kaolinite and illite content, and enriched $\delta^{18} \mathrm{O}$ in $G$. ruber, suggesting dry to semi-dry climate with weakened ISM between 4.4 and $4.2 \mathrm{kyr}$ BP (refs 28, 29) (Figure $3 \mathrm{c}$ ). Ranasinghe et $a l .^{30}$ also suggested sea-level fall near the coast of Sri Lanka after $4 \mathrm{kyr}$ BP. Zorzi et al. ${ }^{31}$ using pollens of sediment cores NGHP-01-16A and NGHP-01-19B from the outlets Mahanadi and Krishna-Godavari from BoB suggested an arid terrestrial climate from $4.2 \mathrm{kyr}$ BP to Present (Figure $3 d$ ). The progressive decrease in ISM intensity between 4.2 and $2.5 \mathrm{kyr}$ BP marked multicentennial shifts towards ecologically contrasting aridity from moisture-loving vegetations. Similar inferences were made using $\mathrm{C}$-isotopes of leaf wax from core NGHP-16A, suggesting increasing aridity in PI between 4.0 and 1.7 kyr BP (ref. 32) (Figure $3 e$ ).

\section{Peninsular India}

The carbon isotopes study from peat deposits of the Nilgiri hills suggested the dominance of $\mathrm{C}_{4}$ grasses between 5 and $2 \mathrm{kyr} \mathrm{BP}$, indicating arid regional climate due to weak ISM $^{33}$. A recent study from the Shantisagara Lake, Karnataka also exhibited an abrupt change in $\mathrm{C}_{\text {org }} / \mathrm{N}$ ratio from 9.1 to 36.6 and very low sand deposition and reduced magnetic susceptibility at $\sim 4.3$ to $3.3 \mathrm{kyr} \mathrm{BP}$, indicating possible drying up of the lake and dominance of terrestrial vegetation $^{34}$ due to declined ISM conditions (Figure $4 a$ ). $\quad \delta^{13} \mathrm{C}_{\text {org }}, n$-alkanes and terrestrial-aquatic ratio from the Ennamangalam lake, Tamil Nadu (Figure $4 \mathrm{~b}$ ) also suggest low terrestrial input with low ISM rainfall between 4.5 and $3.0 \mathrm{kyr} \mathrm{BP}$ (ref. 35). Warrier et al. ${ }^{36}$ suggested an arid phase from 3.7 to $2.0 \mathrm{kyr}$ BP from the Thimmannanayakanakere Lake, Karnataka.

\section{West-Central India}

High-resolution palaeoclimatic records are sparse in WCI covering Middle to Late Holocene transition. A palynological study from the Sapna Lake, Madhya Pradesh shows the dominance of non-arboreal plant taxa over the arboreal ones between 3.8 and $2.7 \mathrm{kyr}$ BP, suggesting an arid climate coupled with weak ISM conditions ${ }^{37,38}$. Another study from the Nitaya Lake, Madhya Pradesh revealed weak monsoon phase between 4.7 and $2.8 \mathrm{kyr}$ BP (ref. 39). Multi-proxy records from the Lonar Lake, Maharashtra indicate a prolonged phase of declining precipitation gradually during the Middle to Late Holocene transition between 4.6 and 3.9 cal kyr BP (Figure $4 c)^{40}$. 


\section{Northeastern India}

The type sample for the Meghalayan age, a speleothem $\delta^{18} \mathrm{O}$ record from the Mawmluh cave, Meghalaya, indicates an abrupt enrichment, suggesting a weakening of the ISM for $\sim 200 \mathrm{yrs}$ at $\sim 4.0 \mathrm{kyr}$ BP (ref. 10) (Figure $4 d$ ). Another speleothem $\delta^{18} \mathrm{O}$ record with a quasi-annual resolution from the same cave suggests multidecadal phases of weak ISM between 4.2 and $3.9 \mathrm{kyr}$ BP (ref. 41). A multi-proxy record from the Pankang Teng Tso Lake, Arunachal Pradesh reveals an arid phase and reduced vegetation growth (Figure $4 e$ ) between 4071 and 3888 cal yrs BP (ref. 42).

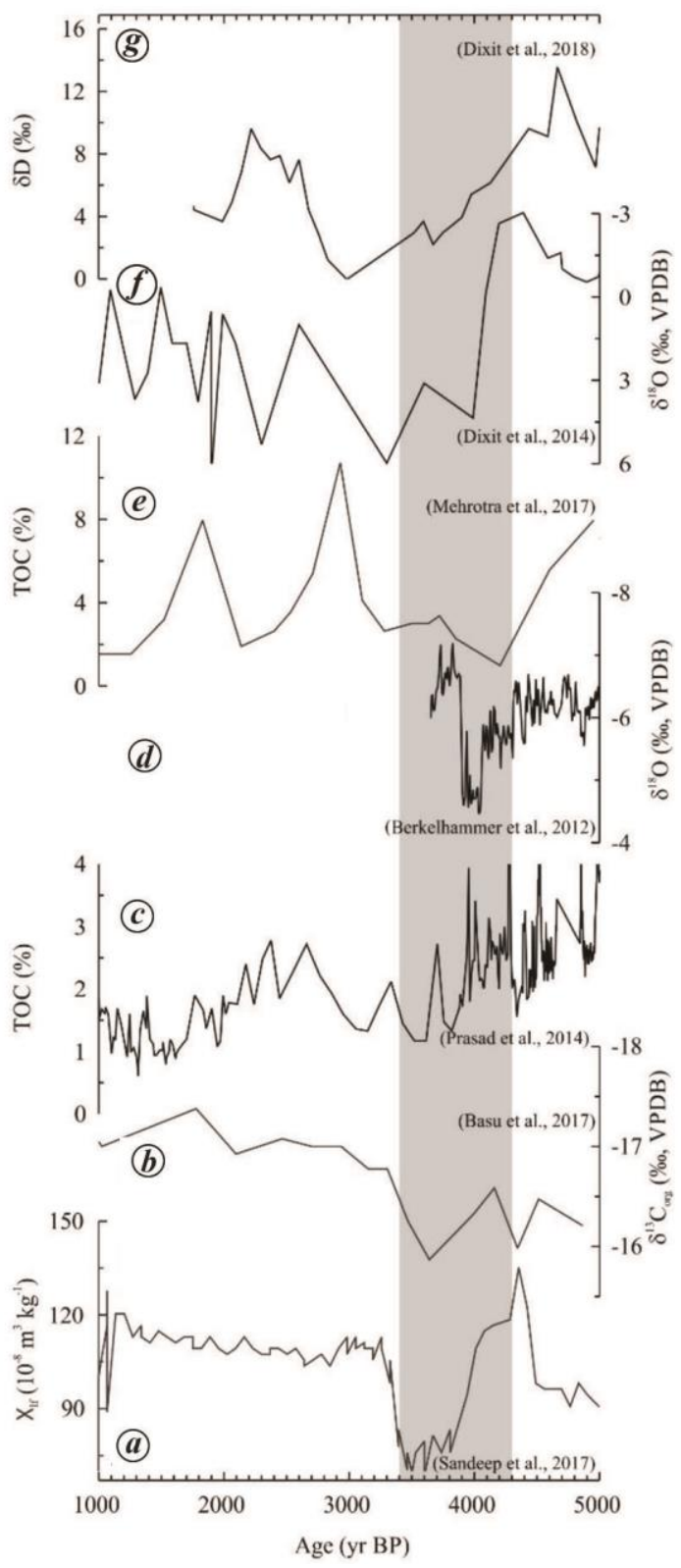

Figure 4. Indian summer monsoon variability proxy records from $(\boldsymbol{a})$ Shantisagara Lake, Karnataka, $\mathrm{PI}^{34}$, (b) Ennamangalwam Lake, $\mathrm{PI}^{35},(\boldsymbol{c})$ Lonar Lake, $\mathrm{WCI}^{40},(\boldsymbol{d})$ Mawmluh cave, $\mathrm{NEI}^{10},(\boldsymbol{e})$ PT Tso Lake, $\mathrm{NEI}^{42}$ $(f)$ Kotla Dahar Palaeolake, NWI ${ }^{8},(g)$ Kharsandi Palaeolake, NWI ${ }^{15}$.

\section{Central Northeast India}

Similar to West-Central India (WCI) there is a paucity of data from Central Northeast India (CNEI). The available records present an unclear picture of climate variability in the region, possibly associated with coarse sampling resolution $^{43-46}$. The records from the Sanai Tal, eastern Uttar Pradesh suggest dry climate because of weak ISM from 5 to 2 kyr BP (ref. 43). However, Jalesar Tal and Lahuradeva Lake from the same area records a warm-wet climate and strengthened ISM between 4.7 and $3.2 \mathrm{kyr}$ BP (ref. 44) and 5.3 to 4.1 kyrs BP (ref. 45) respectively. Studies in the Karela Lake also suggested an increased forest cover linking to strengthened ISM from 4.8 to $2.0 \mathrm{kyr}$ BP (ref. 46).

\section{Northwestern India}

Early records of regional climate variability from Didwana, Lunkaransar and Pushkar lakes from Rajasthan and Nal Sarovar from Gujarat, Northwestern India (NWI), suggested an increased salinity and desiccation after $4.25 \mathrm{kyr} \mathrm{BP}$, indicating reduced precipitation linked with weakened $\mathrm{ISM}^{47,48}$, although the declining water level and increasing salinity were observed since $5.0 \mathrm{kyr}$ BP. The reduced $\mathrm{Ca}$ abundance and enriched $\delta^{18} \mathrm{O}$ from the Kotla Dahar Palaeolake, Haryana also suggested a pronounced weakening of the ISM ${ }^{8}$ for $\sim 200$ yrs between 4.1 and $3.9 \mathrm{kyr} \mathrm{BP}$, however, the results indicate an extension of this arid phase up to $3.5 \mathrm{kyr} \mathrm{BP}$ (Figure $4 f$ ). A recent study from the Kharsandi Palaeolake, Rajasthan also suggests prolonged dry conditions after 4.4 kyr BP (Figure $3 \mathrm{~g})^{15}$. A decrease in precipitation is also inferred from elevated $\delta^{18} \mathrm{O}$ in teeth enamel and bone phosphate at Bhirrana, Haryana ${ }^{49}$. Increased aeolian activity leading to deposition of sand dunes in the region of Drishadvati River, Haryana endorses reduced moisture in the region ${ }^{50}$.

\section{Central Himalaya}

The Rara Lake records from Nepal revealed a weakening of the ISM between 4.3 and 3.9 cal kyr BP (Figure $5 a$ ), accompanied by cold climate conditions ${ }^{51}$. A speleothem $\delta^{18} \mathrm{O}$ record from the Sahiya cave, Uttarakhand ${ }^{52}$ indicates little variations in regional precipitation during $4.2 \mathrm{ka}$ event, although decadal-scale events were observed (Figure $5 \mathrm{~b}$ ). Whereas another speleothem record from the Dharamjali cave, Uttarakhand suggested a stepwise decrease in ISM precipitation from 3.9 to $1.9 \mathrm{kyr}$ BP with prominent multidecadal events ${ }^{14}$ (Figure $5 \mathrm{c}$ ). Palynological study from the Badanital Lake indicated decreased forest vegetation after $4.3 \mathrm{kyr} \mathrm{BP}$ ascribed to cold-arid conditions in the region ${ }^{53}$. A peat record near Dokrani glacier indicated the coldest climate between 4.0 and 3.5 kyr BP during the last 7800 yrs (ref. 54). Recent peat record from Kedarnath also indicates a highly 
fluctuating climate between 5.4 and $3.8 \mathrm{kyr}$ BP with an overall dryness 55 .

\section{Western Himalaya}

The middle to late Holocene transition is suggested as a cold-arid phase in a majority of proxy records from the western Himalaya $^{11,56-59}$ (Figure $5 d-f$ ). Leipe et al. ${ }^{56}$ by pollen analysis from the Tso Moriri Lake, Ladakh suggested the lowest regional precipitation of Holocene between 4.4 and $2.2 \mathrm{kyr}$ BP (Figure $5 d$ ). Another study from the same lake showed a decrease in terrestrial input

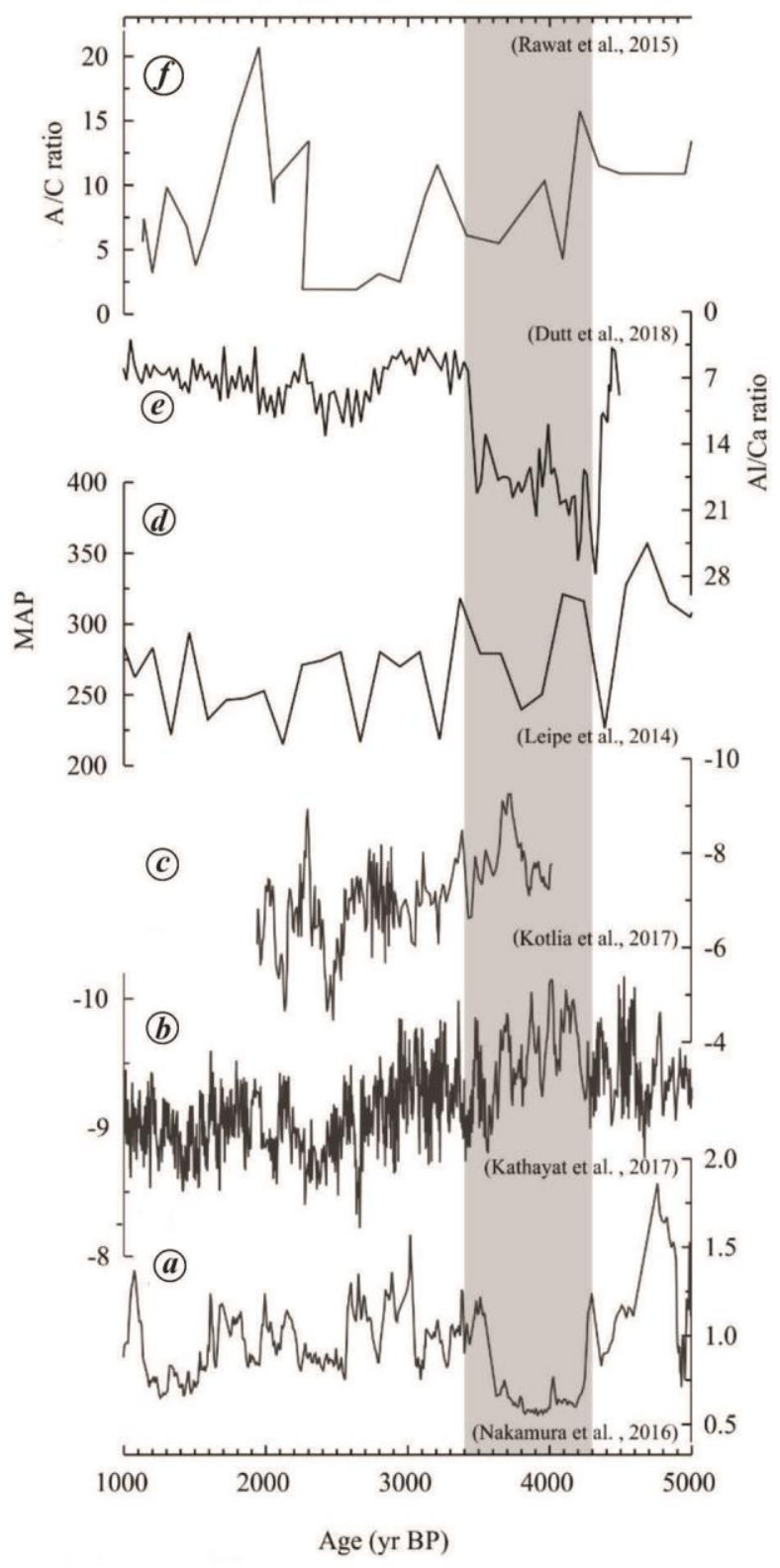

Figure 5. Indian summer monsoon variability proxy records from Nepal and India: $\boldsymbol{a}$, Lake Rara, Nepal ${ }^{52} ; \boldsymbol{b}$, Sahiya cave, central Himalaya ${ }^{53} ; \boldsymbol{c}$, Dharamjali cave, central Himalaya ${ }^{14} ; \boldsymbol{d}$ and $\boldsymbol{e}$, Tso Moriri Lake; western Himalaya ${ }^{11,57} ; \boldsymbol{f}$, Chandra peat bog ${ }^{60}$. between 5.5 and $2.3 \mathrm{cal} \mathrm{kyr} \mathrm{BP,} \mathrm{which} \mathrm{was} \mathrm{more}$ pronounced after $4.2 \mathrm{cal} \mathrm{kyr} \mathrm{BP}$, reaching minimum at $\sim 3.4$ cal kyr BP (ref. 57). This decrease in the terrestrial input can be linked with the reduced moisture output because of weak ISM ${ }^{57}$. Almost similar inferences were drawn by Dutt et al. ${ }^{11}$, indicating abrupt decrease in terrestrial sediments input in the Tso Moriri Lake $\sim 4.35 \mathrm{kyr}$ BP which protracted till $3.45 \mathrm{kyr}$ BP, suggesting weak end ISM conditions (Figure $5 e$ ). Grain size proxies even suggested low precipitation conditions in Ladakh until $2.45 \mathrm{kyr}$ BP (ref. 11). Giosan et al. ${ }^{58}$ suggested a decrease in water discharge in the Indus River and its tributaries in the western Himalaya after $3.9 \mathrm{kyr}$ BP. Multi-proxies record from the Tso Kar Lake suggested high salinity and reduced lake level after $4.8 \mathrm{cal}$ kyr BP to Present due to declined regional precipitation ${ }^{59}$. Chandra peat bog record indicated a short cold-dry spell between $\sim 4808$ and 4327 cal yr BP (refs 60-63).

Majority of proxy records suggest a pronounced ISM weakening beginning at $\sim 4.4$ to $4.0 \mathrm{cal} \mathrm{kyr}$ BP in all the climatic zones of Indian subcontinent, although its amplitude varied temporally and spatially (Figures 2-5). Weak ISM conditions were observed in PI, NWI, central and western Himalaya, and AS for a long interval (5001000 yrs) (refs 8, 11-15, 47, 48, 53, 54, 56-60), whereas NEI experienced dryness for a short interval of $~ 200$ $300 \mathrm{yrs}$ (refs 10, 41, 42). The possible reason for this asynchronicity might be the different behaviour of the ISM in different regions of Indian subcontinent.

\section{2 ka event and its implications on the Indus civilization}

Presently WCI, NWI and CNEI rainfall show a good relationship with all India homogenous rainfall whereas PI and NEI zones become out of phase at times ${ }^{16}$, which could have been the case in past too. Further in regions of low rainfall, e.g. NWI, western Himalaya and parts of south India like Karnataka, fluctuation of few centimeters rainfall is amplified whereas rainfall abundant regions like NEI, Western Ghats, etc. get less affected. Some recent studies also suggest spatial variations in monsoonal precipitation over different basins during the Holocene $^{61,62}$.

Proxy records show a pronounced ISM weakening during the $4.2 \mathrm{ka}$ event which had cascading impacts on socio-economic conditions of IC people ${ }^{8-15}$. Reduced ISM precipitation caused less water availability in Indus river and tributaries ${ }^{13,15,17,59}$. Recently, Giesche et al. ${ }^{9}$ suggest a reduction in westerlies precipitation too in addition to already weak ISM at $\sim 4.3$ to $3.9 \mathrm{kyr}$ BP which imparts additional pressure on regional hydrological regime. Reduced precipitation and river discharge negatively impacted the agriculture and husbandry in the region, a major source for livelihood ${ }^{11,13,15,59}$. Adaptive strategies 


\section{REVIEW ARTICLES}

such as water storage system, increased cultivation of kharif crops, use of drought-resistant seeds, etc. were followed by the IC people to face the early phase of aridity that began $4.2 \mathrm{kyr}$ BP. However, the prolonged droughts repressed the social resilience and adaptations, and caused population migration from west to east for better water availability as visualized through settlements abandonment near Indus and Ghaggar-Hakra regions and establishment of new settlements near Ganga-Yamuna interfluves, which received higher precipitation ${ }^{8,9,11,57,58}$. Significant decrease in number of sites and size of settlements in the western part of the IC testify reduced water resource availability $^{63,64}$.

\section{Forcing factors}

The decrease in solar radiation, cooling in the North Atlantic, appearance of ENSO like conditions in the Pacific Ocean, negative phase of the IOD, southward migration of the ITCZ, and internal variability of the oceans are suggested to be causative factors for the $4.2 \mathrm{ka}$ dry event $\mathrm{t}^{11,15,20,24,40-42,65-76}$. The evidence of an increase in ${ }^{10} \mathrm{Be}$ and a marginal increase in the $\Delta^{14} \mathrm{C}$ during $4.2 \mathrm{ka}$ event demonstrated the possible decline in the solar output which might have triggered such abrupt climate perturbations ${ }^{74}$. However, model and palaeoclimatic reconstruction do not record a prolonged and significant decline in the solar output and cooling in the North Atlantic Ocean ${ }^{69,71-74}$ (Figure 6). The negative phase of IOD-like condition associated with reduced SST in western tropical IO is linked to reduced convection and then summer rainfall over Indian sub-continent ${ }^{2,40,75}$. But such high-resolution records for IOD variability are scatchy and need further investigations. The ENSO has been another major factor to affect the intensity of the $\mathrm{ISM}^{76}$. Strong ENSO activity is known to be linked with low precipitation in the Asian monsoon regime ${ }^{11,65,76}$. Modern ENSO like conditions appeared at $\sim 4.5 \mathrm{kyr}$ BP and intensified at $\sim 4.3 \mathrm{kyr}$ BP (ref. 24) (Figure 6). The strongest ENSO activity existed at $\sim 3.0 \mathrm{ka}$ BP. The high ENSO activity could have been associated with the southward shifting of the ITCZ and weakening of the ISM during $4.2 \mathrm{ka} \mathrm{event}^{11,14}$. The effect of ENSO is much pronounced in NWI, PI, central and western Himalaya while not much significant in northeast India. We anticipate that the strong ENSO activity and associated southward shifting of the ITCZ could have caused prolonged ISM weakening at $\sim 4.2 \mathrm{kyr}$ BP.

A reason for more pronounced weakening in the western zone could also be the eastward shifting of the monsoon belts. The AS branch shifted eastward and as result precipitation in the eastern region remained similar whereas it decreased in southern and western parts of India, but records of Globigerina bulloides from AS, speleothem record from the Qunf cave, Oman and record from Lonar lake suggest a gradual weakening of the summer monsoon from middle to late Holocene $e^{3,40,77}$ and reject this hypothesis. Another possibility might be the weakening of the BoB branch of the ISM $^{78}$, which is associated with decreased rainfall in the Uttarakhand Himalaya. Due to the weakening of the BoB branch, less moisture was supplied to the western side of the Indian sub-continent. The proxy records from India are still sparse and more high-resolution data required to better explain the influence of $4.2 \mathrm{ka}$ event on ISM precipitation in different regions of the Indian subcontinent and possible influencing factors.

\section{Conclusions}

The palaeoclimatic records from the South Asian region indicate highly variable precipitation conditions suggesting

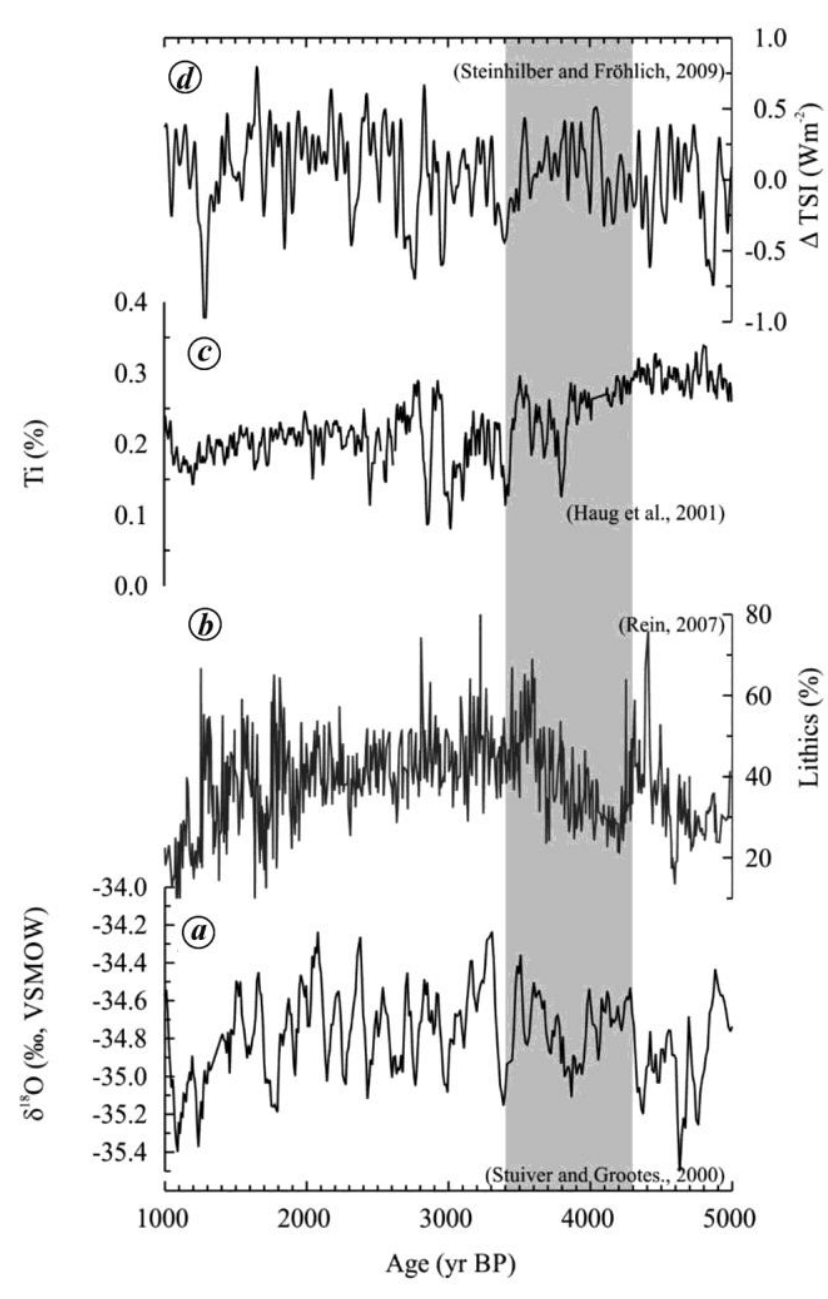

Figure 6. Palaeoclimatic records showing (a) North Atlantic cooling/ warming through oxygen isotopes ratio from GISP 2 ice core, Greenland $^{72}$, (b) El Niño intensity through Lithics (\%) from core SO147$106 \mathrm{KL}$, eastern Pacific Ocean ${ }^{65},(\boldsymbol{c})$ Northward/Southward migration of the Inter 500 Tropical Convergence Zone (ITCZ) through Ti (\%) at ODP Site 1002, Cariaco $\operatorname{Basin}^{70}$ and (d) Total solar irradiance $\left(\Delta \mathrm{TSI}\left(\mathrm{WM}^{-2}\right)^{73}\right.$. 
a complex response of ISM rainfall to forcing factors during the middle to late Holocene transition interval. Prolonged aridity of $\sim 500-1000 \mathrm{yrs}$ is evident in records from southern and northwestern India, central and western Himalaya; however, a short event of 200-300 yrs has been observed in studies from northeastern India. Lake studies from central India and caves from Oman suggest a gradual decline in precipitation during this interval. The strong ENSO activity began around $4.3 \mathrm{kyr}$ BP with a maximum at $\sim 3.0 \mathrm{kyr}$ BP that might have been the major factor for this prolonged arid event during middle to late Holocene transition phase, which triggered migration of population in the Indian subcontinent. More highresolution records are required to better understand ISM behaviour to various forcing factors in different regions of the Indian subcontinent during Northgrippian to Meghalayan shift.

Author contribution. S.D. conceived the idea and wrote the first draft of the manuscript. A.K.G., R.D., R.R.Y. and R.K.S. participated in discussion and preparation of the final draft of the manuscript.

1. Banerji, U. S., Arulbalaji, P. and Padmalal, D., Holocene climate variability and Indian Summer Monsoon: an overview. The Holocene, 2020, 30(5), 744-773.

2. Misra, P., Tandon, S. K. and Sinha, R., Holocene climate records from lake sediments in India: Assessment of coherence across climate zones. Earth-Sci. Rev., 2019, 190, 370-397.

3. Gupta, A. K., Anderson, D. M. and Overpack, J. T., Abrupt changes in the Asian southwest monsoon during the Holocene and their links to the North Atlantic Ocean. Nature, 2003, 421, 354 357.

4. Dutt, S., Gupta, A. K., Clemens, S. C., Cheng, H., Singh, R. K. Kathayat, G. and Edwards, R. L., Abrupt changes in Indian summer monsoon strength during 33,800 to 5500 years BP. Geophys. Res. Lett., 2015, 42, 5526-5532.

5. Yadava, A., Braeuning, A., Singh, J. and Yadav, R. R., Boreal spring precipitation variability in the cold arid western Himalaya during the last millennium, regional linkages, and socio-economic implications. Quat. Sci. Rev., 2016, 144, 28-43.

6. Gupta, A. K., Dutt, S., Cheng, H. and Singh, R. K., Abrupt changes in Indian summer monsoon strength during the last $\sim 900$ years and their linkages to socio-economic conditions in the Indian subcontinent. Palaeogeor., Palaeoclimtol., Palaeoecol., 2019, 536, 109347.

7. Cullen, H. M., Demenocal, P. B., Hemming, S., Hemming, G., Brown, F. H., Guilderson, T. and Sirocko, F., Climate change and the collapse of Akkadian empire: Evidence from the deep sea. Geology, 2000, 28, 379-382.

8. Dixit, Y., Hodell, D. A. and Petrie, C. A., Abrupt weakening of the summer monsoon in northwest India $\sim 4100 \mathrm{yr}$ ago. Geology, 2014, 42, 339-342.

9. Giesche, A., Staubwasser, M., Petrie, C. and Hodell, D., Indian winter and summer monsoon strength over the $4.2 \mathrm{ka}$ BP event in foraminifer isotope records from the Indus River delta in the Arabian Sea. Clim. Past, 2019, 15, 73-90.

10. Berkelhammer, M., Sinha, A., Stott, L., Cheng, H., Pausata, F. S. and Yoshimura, K., An abrupt shift in the Indian monsoon 4000 year ago. In Climates, Landscapes, and Civilizations, AGU Geophysical Monograph Series, 2012, vol. 198, pp. 75-87.
11. Dutt, S., Gupta, A. K., Wünnemann, B. and Yan, D., A long arid interlude in the Indian summer monsoon during $\sim 4,350$ to 3,450 cal. yr BP contemporaneous to displacement of the Indus valley civilization. Quat. Int., 2018, 482, 83-92.

12. Giosan, L. et al., Neoglacial climate anomalies and the Harappan metamorphosis. Clim. Past, 2018, 14, 1669-1686.

13. Staubwasser, M., Sirocko, F., Grootes, P. M. and Segl, M., Climate change at the $4.2 \mathrm{ka}$ BP termination of the Indus valley civilization and Holocene south Asian monsoon variability. Geophys. Res. Lett., 2003, 30, 1425.

14. Kotlia, B. S., Singh, A. K., Joshi, L. M. and Bisht, K., Precipitation variability over Northwest Himalaya from $\sim 4.0$ to $1.9 \mathrm{ka}$ BP with likely impact on civilization in the foreland areas. J. Asian Earth Sci., 2017, 162, 148-159.

15. Dixit, Y. et al., Intensified summer monsoon and the urbanization of Indus civilization in northwest India. Sci. Rep., 2018, 8, 4225.

16. Parthasarathy, B., Kuma, K. R. and Munot, A. A., Homogeneous Indian monsoon rainfall: variability and prediction. Proc. Indian Acad. Sci.-Earth Planet. Sci., 1993, 102, 121-155.

17. Gadgil, S., The Indian monsoon and its variability. Annu. Rev. Earth Planet. Sci., 2003, 31, 429-467.

18. Thamban, M., Kawahata, H. and Rao, V. P., Indian summer monsoon variability during the Holocene as recorded in sediments of the Arabian Sea: timing and implications. J. Oceanograr., 2007, 63(6), 1009-1020

19. Altabet, M. A., Higginson, M. J. and Murray, D. W., The effect of millennial-scale changes in Arabian sea denitrification on atmospheric $\mathrm{CO}_{2}$. Nature, 2002, 415(6868), 159.

20. Das, M., Singh, R. K., Gupta, A. K. and Bhaumik, A. K., Holocene strengthening of the Oxygen Minimum Zone in the northwestern Arabian Sea linked to changes in intermediate water circulation or Indian monsoon intensity? Palaeogeor., Palaeoclimatol., Palaeoecol., 2017, 483, 125-135.

21. Gupta, S. K. and Amin, B. S., Io/U ages of corals from Saurashtra coast. Mar. Geol., 1974, 16(5), M79-M83.

22. von Rad, U., Schaaf, M., Michels, K. H., Schulz, H., Berger, W. H. and Sirocko, F., A 5000-yr record of climate change in varved sediments from the oxygen minimum zone off Pakistan, northeastern Arabian Sea. Quat. Res., 1999, 51(1), 39-53.

23. Arz, H. W., Lamy, F. and Pätzold, J., A pronounced dry event recorded around $4.2 \mathrm{ka}$ in brine sediments from the northern Red Sea. Quat. Res., 2006, 66, 432-441.

24. Burdanowitz, N., Gaye, B., Hilbig, L., Lahajnar, N., Lückge, A., Rixen, T. and Emeis, K. C., Holocene monsoon and sea levelrelated changes of sedimentation in the northeastern Arabian Sea. Deep Sea Res. Part II: Top. Stud. Oceanogr., 2019, 166, 6-18.

25. Sirocko, F., Sarnthein, M., Erlenkeuser, H., Lange, H., Arnold, M. and Duplessy, J. C., Century-scale events in monsoonal climate over the past 24,000 years. Nature, 1993, 364, 322-324.

26. Rashid, H., England, E., Thompson, L. and Polyak, L., Late glacial to Holocene Indian summer monsoon variability based upon sediment records taken from the Bay of Bengal. Terr. Atmos. Ocean Sci., 2011. 22(2), 2.

27. Rashid, H., Flower, B. P., Poore, R. Z. and Quinn, T. M., A $\sim 25 \mathrm{ka}$ Indian Ocean monsoon variability record from the Andaman Sea. Quat. Sci. Rev., 2007, 26, 2586-2597.

28. Achyuthan, H., Nagasundaram, M., Gourlan, A. T., Eastoe, C., Ahmad, S. M. and Padmakumari, V. M., Mid-Holocene Indian summer monsoon variability off the Andaman Islands, Bay of Bengal. Quat. Int., 2014, 349, 232-244.

29. Nagasundaram, M., Achyuthan, H. and Ahmad, S. M., Monsoonal changes inferred from the Middle to Late Holocene sediments off landfall island, North Andaman. Arab. J. Geosci., 2014, 7, 3513 3523.

30. Ranasinghe, P. N., Ortiz, J. D., Moore, A. L., McAdoo, B., Wells, N., Siriwardana, C. H. E. R. and Wijesundara, D. T. D. S., MidLate Holocene coastal environmental changes in southeastern Sri 
Lanka: New evidence for sea level variations in southern Bay of Bengal. Quat. Int., 2013, 298, 20-36.

31. Zorzi, C., Goni, M. F. S., Anupama, K., Prasad, S., Hanquiez, V., Johnson, J. and Giosan, L., Indian monsoon variations during three contrasting climatic periods: The Holocene, Heinrich Stadial 2 and the last interglacial-glacial transition. Quat. Sci. Rev., 2015, 125, 50-60.

32. Ponton, C., Giosan, L., Eglinton, T. I., Fuller, D. Q., Johnson, J. E., Kumar, P. and Collett, T. S., Holocene aridification of India. Geophys. Res. Lett., 2012, 39(3), L03704.

33. Rajagopalan, G., Sukumar, R., Ramesh, R., Pant, R. K. and Rajagopalan, G., Late Quaternary vegetational and climatic changes from tropical peats in southern India - an extended record up to 40,000 years BP. Curr. Sci., 1997, 73(1), 60-63.

34. Sandeep, K. et al., A multi-proxy lake sediment record of Indian summer monsoon variability during the Holocene in southern India. Palaeogeogr., Palaeoclimatol., Palaeoecol., 2017, 476, $1-14$.

35. Basu, S., Anoop, A., Sanyal, P. and Singh, P., Lipid distribution in the lake Ennamangalam, south India: Indicators of organic matter sources and paleoclimatic history. Quat. Int., 2017, 443, 238-247.

36. Warrier, A. K., Shankar, R. and Sandeep, K., Sedimentological and carbonate data evidence for lake level variations during the past 3700 years from a southern Indian lake. Palaeogeogr., Palaeoclimatol., Palaeoecol., 2014, 397, 52-60.

37. Chauhan, M. S. and Quamar, M. F., Pollen records of vegetation and inferred climate change in Southwestern Madhya Pradesh during the last ca. 3800 years. J. Geol. Soc. India, 2012, 80, 470-480.

38. Kumar, O., Devrani, R. and Ramanathan, A. L., Deciphering the past climate and monsoon variability from lake sediment archives of India: a review. J. Clim. Change, 2017, 3, 11-23.

39. Quamar, M. F. and Chauhan, M. S., Late Quaternary vegetation, climate as well as lake-level changes and human occupation from Nitaya area in Hoshangabad District, southwestern Madhya Pradesh (India), based on pollen evidence. Quat. Int., 2012, 263, 104113.

40. Prasad, S. et al., Prolonged monsoon droughts and links to IndoPacific warm pool: A Holocene record from Lonar Lake, central India. Earth Planet. Sci. Lett., 2014, 391, 171-182.

41. Kathayat, G. et al., Evaluating the timing and structure of the $4.2 \mathrm{ka}$ event in the Indian summer monsoon domain from an annually resolved speleothem record from Northeast India. Clim. Past, 2018, 14, 1869-1879.

42. Mehrotra, N., Shah, S. K., Basavaiah, N., Laskar, A. H. and Yadava, M. G., Resonance of the ' 4.2 ka event' and terminations of global civilizations during the Holocene, in the palaeoclimate records around PT Tso Lake, Eastern Himalaya. Quat. Int., 2019 507, 206-216

43. Sharma, S., Joachimski, M. M., Tobschall, H. J., Singh, I. B., Sharma, C. and Chauhan, M. S., Correlative evidences of monsoon variability, vegetation change and human inhabitation in Sanai lake deposit: Ganga Plain, India. Curr. Sci., 2006, 90, $973-$ 978.

44. Trivedi, A., Chauhan, M. S. and Sharma, A., Late pleistoceneholocene vegetation and climate change in the central Ganga plain: A multiproxy study from Jalesar Tal, Unnao district, Uttar Pradesh. Curr. Sci., 2012, 103, 555-562.

45. Saxena, A., Prasad, V. and Singh, I. B., Holocene palaeoclimate reconstruction from the phytoliths of the lake-fill sequence of Ganga Plain. Curr. Sci., 2013, 104, 1054-1062.

46. Chauhan, M. S., Pokharia, A. K. and Srivastava, R. K., Late Quaternary vegetation history, climatic variability and human activity in the Central Ganga Plain, deduced by pollen proxy records from Karela Jheel, India. Quat. Int., 2015, 371, 144-156.

47. Wasson, R. J., Smith, G. I. and Agrawal, D. P., Late Quaternary sediments, minerals and inferred geochemical history of Didwana
Lake, Thar Desert, India. Palaeogeogr., Palaeoclimatol., Palaeoecol., 1984, 46, 345-372.

48. Enzel, Y. et al., High-resolution holocene environmental changes in the Thar Desert, Northwestern India. Science, 1999, 284, 125128.

49. Sarkar, A. et al., Oxygen isotope in archeological bioapatites from India: Implications to climate change and decline of Bronze Age Harappan civilization. Sci. Rep., 2016, 6, 26555.

50. Dave, A. K., Courty, M. A., Fitzsimmons, K. E. and Singhvi, A. K., Revisiting the contemporaneity of a mighty river and the Harappans: Archeological, stratigraphic and chronometric constraints. Quat. Geochron., 2019, 49, 230-235.

51. Nakamura, A. et al., Weak monsoon event at $4.2 \mathrm{ka}$ recorded in sediment from Lake Rara, Himalayas. Quat. Int., 2016, 397, 349359.

52. Kathayat, G. et al., The Indian monsoon variability and civilization changes in the Indian subcontinent. Sci. Adv., 2017, 3, e1701296.

53. Demske, D., Tarasov, P. E., Leipe, C., Kotlia, B. S., Joshi, L. M. and Long, T., Record of vegetation, climate change, human impact and retting of hemp in Garhwal Himalaya (India) during the past 4600 years. The Holocene, 2016, 26, 1661-1675.

54. Phadtare, N. R., Sharp decrease in summer monsoon strength 4000-3500 cal yr BP in the Central Higher Himalaya of India based on pollen evidence from Alpine Peat. Quat. Res., 2000, 53, $122-129$.

55. Srivastava, P. et al., 8000-year monsoonal record from Himalaya revealing reinforcement of tropical and global climate systems since mid-Holocene. Sci. Rep., 2017, 7(1), 14515.

56. Leipe, C., Demske, D., Tarasov, P. E. and HIMPAC project members, A Holocene pollen record from the northwestern Himalayan lake Tso Moriri: Implications for palaeoclimatic and archaeological research. Quat. Int., 2014, 348, 93-112.

57. Mishra, P. K. et al., Reconstructed late Quaternary hydrological changes from Lake Tso Moriri, NW Himalaya. Quat. Int., 2015, 371, 76-86.

58. Giosan, L. et al., Fluvial landscapes of the Harappan civilization. Proc. Natl. Acad. Sci. USA, 2012, 109, E1688-E1694.

59. Wünnemann, B. et al., Hydrological evolution during the last $15 \mathrm{kyr}$ in the Tso Kar lake basin (Ladakh, India), derived from geomorphological, sedimentological and palynological records. Quat. Sci. Rev., 2010, 29, 1138-1155.

60. Rawat, S., Gupta, A. K., Sangode, S. J., Srivastava, P. and Nainwal, H. C., Late Pleistocene-Holocene vegetation and Indian summer monsoon record from the Lahaul, Northwest Himalaya, India. Quat. Sci. Rev., 2015, 114, 167-181.

61. Basu, S., Sanyal, P., Sahoo, K., Chauhan, N., Sarkar, A. and Juyal, N., Variation in monsoonal rainfall sources (Arabian Sea and Bay of Bengal) during the late Quaternary: Implications for regional vegetation and fluvial systems. Palaeogeor., Palaeoclimatol., Palaeoecol., 2018, 491, 77-91.

62. Mishra, P. K. et al., Contrasting pattern of hydrological changes during the past two millennia from central and northern India: Regional climate difference or anthropogenic impact? Global Planet. Change, 2018, 161, 97-107.

63. Possehl, G. L., Climate and the eclipse of ancient cities of Indus. In Third Millennium BC Climate Changes and Old World Collapse (eds Dalfes, H. N., Kukla, G. and Weiss, H.), Springer, Heidelberg, 1997, pp. 193-243.

64. Dutt, S., Gupta, A. K., Singh, M., Jaglan, S., Saravanan, P., Balachandiran, P. and Singh, A., Climate variability and evolution of the Indus civilization. Quat. Int., 2019, 507, 15-23.

65. Rein, B., How do the $1982 / 83$ and $1997 / 98$ El Niños rank in a geological record from Peru? Quat. Int., 2007, 161, 56-66.

66. Bradley, R. and Bakke, J., Is there evidence for a $4.2 \mathrm{ka}$ BP event in the northern North Atlantic region? Clim. Past, 2019, 15, 16651676 . 


\section{REVIEW ARTICLES}

67. Jalali, B., Sicre, M. A., Azuara, J., Pellichero, V. and Combourieu-Nebout, N., Influence of the North Atlantic subpolar gyre circulation on the 4.2 ka BP event. Clim. Past, 2019, 15, 701-711.

68. Toth, L. T. and Aronson, R. B., The $4.2 \mathrm{ka}$ event, ENSO, and coral reef development. Clim. Past, 2019, 15, 105-119.

69. Perry, C. A. and Hsu, K. J., Geophysical, archaeological, and historical evidence support a solar-output model for climate change. Proc. Natl. Acad. Sci. USA, 2000, 97(23), 12433-12438.

70. Haug, G. H., Hughen, K. A., Sigman, D. M., Peterson, L. C. and Röhl, U., Southward migration of the Intertropical Convergence Zone through the Holocene. Science, 2001, 293, 1304-1308.

71. Bond, G. et al., Persistent solar influence on North Atlantic climate during the Holocene. Science, 2001, 294(5549), 2130-2136.

72. Stuiver, M. and Grootes, P. M., GISP2 oxygen isotope ratios Quat. Res., 2000, 53(3), 277-284.

73. Steinhilber, F., Beer, J. and Fröhlich, C., Total solar irradiance during the Holocene. Geophys. Res. Lett., 2009, 36(19), L19704.

74. Mayewski, P. A. et al., Holocene climate variability. Quat. Res., 2004, 62(3), 243-255.

75. Abram, N. J., McGregor, H. V., Gagan, M. K., Hantoro, W. S. and Suwargadi, B. W., Oscillations in the southern extent of the IndoPacific Warm Pool during the mid-Holocene. Quat. Sci. Rev., 2009, 28, 2794-2803.
76. Kumar, K. K., Rajagopalan, B., Hoerling, M., Bates, G. and Cane, M., Unraveling the mystery of Indian monsoon failure during El Niño. Science, 2006, 314, 115-119.

77. Fleitmann, D., Burns, S. J., Mudelsee, M., Neff, U., Kramers, J., Mangini, A. and Matter, A., Holocene forcing of the Indian monsoon recorded in a Stalagmite from Southern Oman. Science, 2003, 300, 1737-1739.

78. Sinha, A. et al., Trends and oscillations in the Indian summer monsoon rainfall over the last two millennia. Nat. Commun., 2015, 6, 6309 .

ACKNOWLEDGEMENTS. S.D. thanks the Director, Wadia Institute of Himalayan Geology for proving necessary infrastructure facilities during this work. A.K.G. thanks Department of Science and Technology, New Delhi for J.C. Bose Fellowship. R.R.Y. acknowledges the support of the Council of Scientific and Industrial Research, New Delhi under the Emeritus Scientist scheme (No. 21(1010)/15/EMR-II).

Received 14 February 2020; revised accepted 10 March 2021

doi: $10.18520 / \mathrm{cs} / \mathrm{v} 120 / \mathrm{i} 9 / 1449-1457$ 